Zagazig J. Agric. Res., Vol. 43 No. (6B) 2016

http:/www.journals.zu.edu.eg/journalDisplay.aspx?Journalld=1\&queryType=Master

\title{
ASSESSMENT OF ANTIDIABETIC ACTIVITY OF (Physalis pubescens L.) IN RUSK
}

\author{
Hanan S. Shalaby ${ }^{1}$, Ghada M. El-Araby ${ }^{2}$ and A.E. Awad ${ }^{3 *}$ \\ 1. Food Sci. Dept., Fac. Agric., (Rural Home Econ.), Zagazig Univ., Egypt \\ 2. Food Sci. Dept., Fac. Agric., Zagazig Univ., Egypt \\ 3. Agric. Biochem. Dept., Fac. Agric., Zagazig Univ., Egypt
}

\begin{abstract}
This study was carried out to evaluate the chemical composition and sensory evaluation of Rusk containing physalis paste at ratio of $10 \%$ and $20 \%$. There were no significant difrences between Physalis Rusk and control samples in the organoleptic properties. Also, in this study, healthy and nutritional values of Physalis Rusk was studied. Diabetic rats were fed on 5\% Physalis Rusk (containing 10\% and 20\% physalis). Blood glucose, liver and kidney functions were determined in blood serum. Histopathalogical studies on liver, pancreas and kidney sections were carried out. Results showed that diabetic rats which fed on physalis Rusk had low blood glucose, total cholesterol, triglycerides and low density lipoprotein. While, high density lipoprotein was increased. Results revealed an improve in liver, pancreas and kidney of rats fed on physalis Rusk. Liver, pancreas and kidney sections of physalis Rusk rats were improved compared with control diabetic rats. From the foregoing results in the current work, it could be recommended to add physalis paste at a ratio of 10 or $20 \%$ during the manufacture of Rusk to get the healthy and nutritional benefits of this product.
\end{abstract}

Key words: Physalis, rusk, diabetic rats, antidiabetic, hypolipidemic, histopathology.

\section{INTRODUCTION}

Diabetes is a deadly disease that affected an estimated 285 million people worldwide in 2010 and the number is increasing in rural and poor populations throughout the world and is projected to become one of the world's main disablers and killers within the next 25 years (Shaw et al., 2010).

The diabetic effect of alloxan is due to an excess in the production of reactive oxygen species (ROS). This excess leads to toxicity in pancreatic cells, which, in turn, reduces the synthesis and release of insulin while concurrently affecting other organs, such as liver. The pancreatic-cells are highly vulnerable to oxidative stress as a result of their intrinsically low expressions and activities of

\footnotetext{
* Corresponding author: Tel. : +201229489865

E-mail address: Hanan Shalaby31@yahoo.com
}

free radical scavenging enzymes. (Hassan and Ghoneim, 2013).

Physalis is an dean specie whose fruits are eaten as food and also has been reported in Colombian folk medicine for diabetes mellitus treatment (Diana et al., 2015). The physalis could be considered as a potential candidate for developing a new anti-diabetic agent. Through, offers promising antidiabetic effects that may be mainly attributed to its potent antioxidant potential (Hassan and Ghoneim, 2013).

Physalis juice yield is about $70 \%$ of the fruit weight (Ramadan and Mörsel, 2007). Sugar content in the juice is $5 \mathrm{~g} / 100 \mathrm{~g}$ and the main compounds are fructose and sucrose. Ascorbic acid level in physalis was found $46 \mathrm{mg} / 100 \mathrm{~g}$ turns out to be higher than in most fruits such as pear and peach (7 mg/100 g), and somewhat 
comparable with orange (50 mg/100 g). In physalis, quercetin was the main phenolic compound, followed by myricetin and kaempferol (Häkkinen et al., 1999). Physalis juice is rich in water and fat-soluble bioactive compounds and could be a novel source of functional drinks (Ramadan, 2011).

Rusk is traditional hard, dry bread that South Africans love to dunk in their tea and coffee in the morning (or any time of the day, really). They became popular during the Groot Trek (the great trek), when Africans needed a way of preserving bread as they travelled across the country in ox wagons. Rusk comes in all shapes, sizes and flavours, from butter milk to double chocolate to muesli. Rusk is a type of bakery product attributed with prolonged shelf-life beneficial in certain diets (Fliiopovic et al., 1991). Generally, market is offering a poor assortment of Rusk-type products, particularly Rusk of altered nutritive value. The period between seventies and eighties of the 20 th century is marked as the decade of alimentary fibers, since it has been estimated that diet of technologically developed society and town population is characterized by high content of energy and small consumption of alimentary fibers. By adding Physalis to Rusk, its attributes concerning functional food, are significantly increased. Rusk is becoming the food with authentic claims on both the short and long term health gains (Fliiopovic and Gyura, 2007).

The aim of the work was to study the chemical properties of physalis Rusk product. Also, biological experiment and histopathology were carried out to study the effect of feeding rats on Rusk containing Physalis at different percentages .

\section{MATERIALS AND METHODS}

\section{Material}

Fruits of Physalis were collected from local market (Zagazig, Egypt). The fruits were carefully selected according to the degree of ripeness measured by fruit colour (brilliant orange). Fruits were dehusked, washed, crushed at room temperature using electrical grinder, which was then stored in an airtight brown container at $5^{\circ} \mathrm{C}$ until further use. Alloxan monohydrate and kits (total cholesterol, triacylglycerol and total high -density lipoprotein cholesterol (HDL-C), total protein (ALT, AST, creatinine and urea were purchased form Sigma-Aldrich (MO,IL USA) .Reagents and chemicals used were of the highest purity.

\section{Chemical Analyses}

\section{Chemical composition of physalis fruits and rusk}

Moisture, crude protein, fat, total dietary fibre and ash contents of Physalis fruits and Physalis Rusk (PR) were determined by the standard procedures described in the AOAC (2010). Total carbohydrates were calculated by difference according to the following equation:

Total carbohydrates $=100$ - $($ Moisture $\%+$ crude protein $\%+$ crude fat $\%+$ ash $\%+$ total crude dietary fibre \%).

\section{Preparation of Rusk}

Rusk was prepared in the laboratory in pilot plant following bread formula practiced: white flour (ash content $0.52 \%$ DM, protein content $7.7 \%$ DM) 5\% baker's yeast - 3\%, salt. All materials were commercial grade and water was added according to farinograph absorption. The dough cut in pieces $9 \mathrm{~cm}$ thickness. Control samples (C) without Physalis, T1and T2 containing $10 \%$ and $20 \%$, respectively. The dough was baked in the oven at $200^{\circ} \mathrm{C}$, approximately $10 \mathrm{~min}$, until light brown colour according to standard AACC baking procedure. After cooling at ambient temperature. Rusk was packed in packaging materials until study (Filipovic et al., 2012).

\section{Sensory evaluation of Rusk}

The samples of Rusk were evaluated by 15 panellists, Department of Food Sciences ,Faculty of Agriculture, University of Zagazig. Attributes recognized by the sensory panel as describing the sensory properties of the rusk products were: appearance colour, flavour, taste, texture and over all acceptability (Olaoye and Onilude, 2008). The hedonic scale has 9 levels: the first four levels (1-4) show the positive sensations and the last four (6-9) show the negative sensations. The results are statistically analyzed using multiple correspondence analyses. 


\section{Biological Experiment}

\section{Experimental animals}

The work was carried out in Biochemistry Department, Faculty of Agriculture, Zagazig University, Egypt. Healthy male albino rats weighing 170-190 g, were obtained from Helwan Experimental Station, and used in this investigation. The rats were housed in stainless steel cages with screen bottom in a controlled environment with $12 \mathrm{hr}$., light and $12 \mathrm{hr}$., dark cycles. Water was available over period.

All groups were fed on the basal diet for 2 weeks as adaptation period. The basal diet consisted of $15 \%$ casein, $5 \%$ cellulose, $10 \%$ fat and $65 \%$ corn starch. Salt and vitamin mixtures were added at a ratio of $4 \%$ and $1 \%$, respectively according to AOAC (2010).Water was given ad libitum. The experiment lasted for 6 weeks and the animals were divided into 5 groups, 6 rats each.

\section{Induction and assessment of diabetes}

Diabetes was induced in twenty four male rats by a single intra peritoneal injection of alloxan $150 \mathrm{mg} / \mathrm{kg}$ (Jelodar et al., 2010). The animals were allowed to drink 5\% glucose solution to overcome the drug (Balasubramaian et al., 2004). Fasting blood glucose levels were measured after 2 days. Animal had blood glucose concentration level above $185 \mathrm{mg} / \mathrm{dl}$ were considered to be alloxanized diabetic rat and used in this study. Diabetes has been shown after about 2 days of alloxan injection. Blood glucose levels of the rats were monitored basis with a Glucometer -elite commercial test (Bayer), based on the glucose oxidase method throw 2 days. Blood samples were collected from the tip of tail at the defined time patterns (Aslan et al., 2007a,b). The blood samples have been collected after 3 and 6weeks feeding and analysed by enzymatic kit method (Young, 2001).

\section{Experimental design}

Male rats have been selected at a random way. All rats were fed on basal diet (20g. daily per rat) for one week (adaptation period). Rat groups were divided into five groups, (each group 6 animals). Group1 (G1): Rats fed on basal diet (diabetic free) and considered to be as negative control. The other 4 groups (diabetic animals) Group2 (G2): positive control. Group3 (G3): fed on Rusk without physalis. Group4 (G4):fed on (PR10\%). Group5 (G5): fed on (PR 20\%). Diabetic rats were fed 5\% (G3,G4,G5).

\section{Blood and tissue analyses}

Blood samples were collected from the eye plexuses under diethyl ether anesthesia after 3 , and 6weeks from the start. The samples were collected in tubes and were centrifuged at 3000 rpm for $20 \mathrm{~min}$ to obtain serum. The total cholesterol was analyzed according to Young (2001), triglyceride was analyzed according to Stein (1987), (HDL-C) was measured by enzymatic colorimetric method using Randox kits (Gordon, 1977) and the concentration of (LDLC) cholesterol was calculated by the following equation: $\mathrm{LDL}-\mathrm{C}=(\mathrm{T} . \mathrm{C}-\mathrm{HDL})-\mathrm{T} . \mathrm{G} / 5$

A liver enzyme activates, alanine amino transferase (ALT), aspartate amino transferase (AST) and total protein were analyzed according to Young (2001). Kidney functions in serum creatinine and blood urea nitrogen were determined according to Young (2001).

\section{Statistical Analysis}

The results concerning physalis Rusk (moisture content and acidity) were statistically tested by analysis of multi variance ANOVA and discriminative test. ANOVA functions and Roy test both with 0.05 significance level were used as Unitarian statistical procedures to assess significant differences among means (Steel and Torrie,1980).

\section{Histopathological Examination}

Specimens from liver, kidney and pancreas from all groups were examined macroscopically then fixed in $10 \%$ neutral formalin and embedded in paraffin. Sections of five microns thickness were prepared, stained by hematoxlin and eosin as mentioned by Suvarna et al. (2013) and examined microscopically. 


\section{RESULTS AND DISCUSSION}

\section{Chemical Composition of Physalis Fruit and Rusk Product}

The analyses of physalis fruit and Rusk product is recorded in Table 1. Data showed that physalis fruit composition was, moisture $(80.17 \%)$, protein $(1.92 \%)$, fat $(2.16 \%)$, fiber $(1.97 \%)$, ash $(0.9 \%)$ and carbohydrate (12.88\%).These results are similar to results obtained by Ramadan and Moersel (2004) who stated that compositions of physalis peruviana were expressed in $\mathrm{g} / 100 \mathrm{~g}$ moisture $80.97 \pm$ 1.65; total lipids $3.16 \pm 0.32$; proteins $1.85 \pm$ 0.31 ; total carbohydrates 13.22 ; ash $0.80 \pm 0.03$.

Data showed that Rusk product composition (T2) had high moisture and protein, fat, fiber and ash contents $(4.32 \%, 9.22 \%, 43.37 \%$, $3.25 \%$, and $1.65 \%$ respectively and lowest level of carbohydrate (38.19\%) compared with control.

The sensorial quality of food products plays an important role in the choice of food. Hedonic testing is often used to determine consumers attitude towards the food by measuring a degree of acceptance of a new product or improving the existing food product (Meilgard et al., 1991 ; Poster, 1991).

Sensory evaluation of Rusk was evaluated for appearance, colour, flavour, taste, texture and overall acceptability. Table 2 illustrate sensory evaluation of Rusk containing different concentrate of physalis. The results proved no significantly differences $(\mathrm{P}<=0.05)$ between the control and fortified samples. All samples showed good evaluation and high values than 6.00. Finely physalis was used as research material. It was demonstrated that the addition of physalis paste resulted in a significant improvement in properties of Rusk acceptability.

\section{Impact of Feeding Physalis Rusk on the Serum Profile}

\section{Blood glucose}

Data in Table 3 show the levels of blood glucose contents of rats fed diets containing different levels of physalis Rusk at different periods during the experiment. At the beginning of the experiment group fed on basal diet (-Ve group) and diabetic group (+Ve group) has a blood glucose 112.72 and 220.34 (g/dl), respectively. The data showed a significant decrease in blood glucose level as a result of feeding rats on $20 \%$ PR (G5), then $10 \%$ PR (G4) through 3 weeks and 6 weeks compared with the alloxan diabetic rats (G2). This effect may be due to the antioxidant of physalis which neutralize the biological effects of alloxan induced diabetes as well as the oxidative stress as reported by Hassan and Ghoneim,(2013).

Blood glucose control is an important component in delaying or preventing acute or long-term diabetic complications. Oral administration of Physalis peruviana L. fruits extract to diabetic rats reduces the blood glucose concentrations without causing hypoglycaemic state, probably due to insulin secretion from surviving beta cells (Murugesan and Subramanian, 2015).

\section{Impact of Physalis Rusk on the Serum Lipid Profile}

The oxidation of lipids and proteins in lipoprotein and cell membranes lead to impairment of lipid transport and to cell injury and thereby contributes to development of various diseases (Gutteridge, 1995).

The metabolism of free and ester cholesterol is impaired in liver, spleen and thymus tissue, and the rate of turnover is specifically decreased in all tissues of rats under stress (Choi et al., 2001; Feoli et al., 2003).

There is a metabolic link between the expanded body fat, high levels of triglycerides (TG), low density lipoprotein cholesterol (LDL$\mathrm{C})$, and lowering high-density lipoprotein cholesterol (HDL-C) and insulin resistance, which leads to impaired metabolic regulation in adipose tissue and flux of free fatty acids (FFA) (Despres, 2006). Such flux of FFA toward the liver results in TG accumulation and secretion of TG-rich lipoproteins, which in turn affects the distribution of lipoprotein subtypes and the activity of lipolipase. Pandey and Rizvi (2010) reported increase levels of lipid peroxidation in diabetic rats. 
Table 1. Chemical composition of physalis fruit and Rusk product

\begin{tabular}{lcccccc}
\hline Sample & $\begin{array}{c}\text { Moisture } \\
\mathbf{( \% )}\end{array}$ & $\begin{array}{c}\text { Protein } \\
\mathbf{( \% )}\end{array}$ & $\begin{array}{c}\text { Fat } \\
\mathbf{( \% )}\end{array}$ & $\begin{array}{c}\text { Total fiber } \\
\mathbf{( \% )}\end{array}$ & $\begin{array}{c}\text { Ash } \\
\mathbf{( \% )}\end{array}$ & $\begin{array}{c}\text { Carbohydrates } \\
\mathbf{( \% )}\end{array}$ \\
\hline Physalis fruit & 80.17 & 1.92 & 2.16 & 1.97 & 0.9 & 12.88 \\
C & 4.02 & 8.77 & 28.05 & 0.40 & 0.55 & 58.21 \\
T1 & 4.24 & 8.99 & 34.25 & 2.90 & 0.90 & 48.72 \\
T2 & 4.32 & 9.22 & 43.37 & 3.25 & 1.65 & 38.19 \\
\hline
\end{tabular}

C: Rsuk control

T1: Rusk containing $10 \%$ physalis

T2 : Rusk containing 20\% physalis

Table 2. Sensory evaluation of Rusk product

\begin{tabular}{lcccccc}
\hline Sample & $\begin{array}{c}\text { Appearance } \\
\text { (9) }\end{array}$ & $\begin{array}{c}\text { Colour } \\
\mathbf{( 9 )}\end{array}$ & $\begin{array}{c}\text { Flavour } \\
\mathbf{( 9 )}\end{array}$ & $\begin{array}{c}\text { Taste } \\
\mathbf{( 9 )}\end{array}$ & $\begin{array}{c}\text { Texture } \\
\text { Acceptability }\end{array}$ & $\begin{array}{c}\text { (9) } \\
\text { (9) }\end{array}$ \\
\hline C & $7.58^{\mathrm{a}}$ & $7.92^{\mathrm{a}}$ & $8.08^{\mathrm{a}}$ & $8.42^{\mathrm{a}}$ & $7.92^{\mathrm{a}}$ & $8.42^{\mathrm{a}}$ \\
T1 & $7.00^{\mathrm{b}}$ & $7.33^{\mathrm{b}}$ & $6.92^{\mathrm{b}}$ & $7.50^{\mathrm{b}}$ & $7.42^{\mathrm{b}}$ & $8.00^{\mathrm{a}}$ \\
T2 & $6.67^{\mathrm{b}}$ & $6.92^{\mathrm{b}}$ & $6.25^{\mathrm{c}}$ & $7.17^{\mathrm{b}}$ & $7.42^{\mathrm{b}}$ & $8.08^{\mathrm{a}}$ \\
LSD & 0.398 & 0.550 & 0.459 & 0.447 & 0.375 & 0.537 \\
\hline
\end{tabular}

Values with different letters in the same column or row are significantly different $(\mathrm{P}<0.05)$

Table 3. Impact of feeding Physalis Rusk on the levels of serum blood glucose (g/dl)

\begin{tabular}{lcc}
\hline Group & \multicolumn{2}{c}{ Blood glucose (g/dl) } \\
\cline { 2 - 3 } & 3 weeks & 6 weeks \\
\hline G1 & $112.72^{\mathrm{d}}$ & $119.05^{\mathrm{c}}$ \\
G2 & $220.34^{\mathrm{b}}$ & $286.54^{\mathrm{a}}$ \\
G3 & $190.65^{\mathrm{bc}}$ & $170.48^{\mathrm{b}}$ \\
G4 & $179.33^{\mathrm{bc}}$ & $113.96^{\mathrm{c}}$ \\
G5 & $154.38^{\mathrm{cd}}$ & $115.51^{\mathrm{c}}$ \\
LSD & 57.479 & 50.672 \\
\hline
\end{tabular}

Values with different letters in the same column or row are significantly different $(\mathrm{P}<0.05)$
G1 : normal group(-Ve)
G2 : diabetic group $(+\mathrm{Ve})$
G3: diabetic group and fed 5\% Rusk
G4: diabetic group and fed 5\%PR(PR containing 10\% physalis)
G5: diabetic group and fed 5\%PR (PR containing 20\% physalis) 
Results in Table 4 show that TC, TG and LDL-C significantly decreased in group G5(diabetic and feeding 20\% PR) and had the lowest level TC, LDL-C,TG while having the highest level of HDL-C in comparison with the G2 (diabetic and feeding normal) and G3 (diabetic and feeding 10\% Rusk free physalis).The results are in line with (Ramadan et al., 2013) who stated that the administration of golden berry has a profound influence on the metabolism of lipids. Golden berry had positive affects on the blood profile of rats. The TC, LDL and TG concentrations in the golden berry diet groups were significantly lower than those in the positive control group. The positive influence on blood lipids was high in the groups of rats fed on golden berry, which possesses high antioxidant potential.

\section{Impact of Physalis Rusk on the Liver and Kidney Functions}

Table 5 shows the effect of administrating physalis Rusk on the liver functions (ALT and AST) of diabetic rats. Diabetic and feeding normal (G2) was characterized by a significant increase in ALT. The highest level of ALT was $80 \mathrm{U} / \mathrm{L}$ in the G2 (diabetic and feeding normal), while the levels 67-74 U/L were noted in groups fed with physalis Rusk. The increase in serum ALT activity indicates liver cell necrosis and hepatic injury. Treatment with physalis Rusk induced a decrease in the high activity of ALT and the levels were decreased compared with the positive control group after 6weeks of administration. Also, G2 (diabetic and feeding normal) was characterized by an increase in AST. The increase of AST activity was more specific for cardiac injury. The amounts of AST were 64-67 U/L in groups fed physalis Rusk. The highest level of AST was $74 \mathrm{U} / \mathrm{L}$ in the positive control group. ALT and AST were high as shown in Table 5. The data agree with those of Daher et al. (2006).

Diabetic state was accompanied by decrease in total serum protein (Table 5).Total protein value for group 2 (diabetic and feeding normal) was $7.21 \mathrm{gm} / \mathrm{dl}$ after three weeks, where in the values were lower for groups treated with physalis Rusk (4.38-6.8 mg/dl) after 6 weeks total protein were 6.74 for group 5 and 6.89 for group 4.
The diabetes was accompanied by an increase in kidney function parameters. Feeding on physalis Rusk resulted in reduction of creatinine and urea levels at the period of the experiment. A decreased excretion of urea was observed in infected liver (urea-producing organ) and in impaired glomerular filtration of blood. According to the obtained results presented in Table 6, rat groups fed on physalis Rusk (G4, G5) recorded lower urea levels (39 $\mathrm{mg} / \mathrm{dl}$ ) after 6 weeks.

Feeding Physalis Rusk may enhance the ability of the kidney to remove these waste products from the blood, as indicated by a protective effect on the kidney of diabetic rats.

An increase in serum level of urea and creatinine levels in Streptozotocin (STZ) diabetic rats may indicate diminished ability of the kidney to filter these waste products from the blood and excrete them in the urine (Parminder et al., 2012).

\section{Histopathological examination}

Histopathological tissues of the rats liver, pancreas, and kidney is shown in Figs. (1-15).

Liver, pancreas and Kidney tissues indicated that the normal configuration of hepatic tissues without any abnormality and liver sinusoids and kupffer cells were morphologically normal (Fig. 1). Microscopic examination of pancreas showed that all the components of pancreas including the endocrine and exocrine portions were normal (Fig.2). Kidney tissue was normal (Fig. 3).

It is observed in Fig. 4 that liver had severe congestion or telangiectasia due to severe widening of hepatic sinusoids could be seen. Portal area edema, lymphocytic aggregations, proliferation of numerous bile ductules and hyperplastic kupffer cells could be seen. Fig. 5 show that Islets of Langerhans was hypocellularity, vacuolated cytoplasm, pyknotic and karyorrhexis of nuclei and edema in pancreas. Renal tubular epithelium cells appeared necrotic due to pyknotic nuclei together with congested glomerular tufts and capillaries were noticed. Focal nephrotic changes as vacuolated cytoplasm or acute cell swelling were also observed in Kidney tissue (Fig. 6). 
Table 4. Impact of Physalis Rusk on the serum lipid profile

\begin{tabular}{|c|c|c|c|c|}
\hline Lipid profile & $\begin{array}{c}\text { Triglyceride } \\
\text { (mg/dl) }\end{array}$ & $\begin{array}{c}\text { Total cholesterol } \\
(\mathrm{mg} / \mathrm{dl})\end{array}$ & $\begin{array}{c}\text { HDL } \\
\text { (mg/dl) }\end{array}$ & $\begin{array}{c}\text { LDL } \\
(\mathrm{mg} / \mathrm{dl})\end{array}$ \\
\hline -Ve: normal group(negative) & $119.16^{\mathrm{bc}}$ & $125.91^{b}$ & $52.04^{\mathrm{ab}}$ & $50.08^{\mathrm{C}}$ \\
\hline +Ve : diabetic group(positive) & $139.47^{\mathrm{a}}$ & $138.58^{a}$ & $42.31^{\mathrm{b}}$ & $68.38^{\mathrm{a}}$ \\
\hline
\end{tabular}

Feeding period 3 weeks 6 weeks 3 weeks 6 weeks 3 weeks 6 weeks 3 weeks 6 weeks

Group

\begin{tabular}{lcccccccc} 
G1 & $119.52^{\mathrm{bc}}$ & $144.22^{\mathrm{a}}$ & $128.22^{\mathrm{b}}$ & $102.00^{\mathrm{c}}$ & $54.11^{\mathrm{ab}}$ & $56.14^{\mathrm{b}}$ & $50.22^{\mathrm{c}}$ & $17.01^{\mathrm{d}}$ \\
G2 & $127.95^{\mathrm{ab}}$ & $164.20^{\mathrm{a}}$ & $131.26^{\mathrm{b}}$ & $120.67^{\mathrm{b}}$ & $45.46^{\mathrm{ab}}$ & $46.83^{\mathrm{d}}$ & $60.18^{\mathrm{b}}$ & $47.50^{\mathrm{b}}$ \\
G3 & $111.74^{\mathrm{c}}$ & $112.80^{\mathrm{b}}$ & $101.50^{\mathrm{c}}$ & $91.38^{\mathrm{d}}$ & $48.84^{\mathrm{ab}}$ & $46.37^{\mathrm{d}}$ & $30.31^{\mathrm{d}}$ & $22.85^{\mathrm{c}}$ \\
G4 & $116.82^{\mathrm{bc}}$ & $117.99^{\mathrm{b}}$ & $100.09^{\mathrm{cd}}$ & $98.34^{\mathrm{cd}}$ & $47.13^{\mathrm{b}}$ & $58.15^{\mathrm{ab}}$ & $19.61^{\mathrm{e}}$ & $16.59^{\mathrm{d}}$ \\
G5 & $116.97 \mathrm{~b}^{\mathrm{c}}$ & $113.44^{\mathrm{b}}$ & $93.75^{\mathrm{d}}$ & $92.19^{\mathrm{d}}$ & $57.75^{\mathrm{a}}$ & $60.62^{\mathrm{a}}$ & $12.60^{\mathrm{f}}$ & $8.76^{\mathrm{e}}$ \\
LSD & 13.16 & 12.02 & 6.71 & 7.47 & 13.88 & 3.60 & 3.01 & 3.98 \\
\hline
\end{tabular}

Values with different letters in the same column or row are significantly different $(\mathrm{P}<0.05)$

-Ve (control): normal group $\quad+\mathrm{Ve}$ (control): diabetic group

G1 : normal group(-Ve) G2 : diabetic group(+Ve)

G3: diabetic group and fed 5\% Rusk G4: diabetic group and fed 5\% PR (PR containing 10\% Physalis)

G5: diabetic group and fed 5\%PR (PR containing 20\% Physalis)

Table 5. Impact of Physalis Rusk on the liver functions

\begin{tabular}{|c|c|c|c|c|c|c|}
\hline Lipid profile & \multicolumn{2}{|c|}{$\begin{array}{c}\text { Total protein } \\
\text { (g-dl) }\end{array}$} & \multicolumn{2}{|c|}{$\begin{array}{l}\text { ALT } \\
\text { (U-L) }\end{array}$} & \multicolumn{2}{|c|}{$\begin{array}{l}\text { AST } \\
\text { (U-L) }\end{array}$} \\
\hline -Ve: normal group(negative) & \multicolumn{2}{|c|}{$6.87^{\mathrm{a}}$} & \multicolumn{2}{|c|}{$74.50^{\mathrm{a}}$} & \multicolumn{2}{|c|}{$76.00^{\text {ab }}$} \\
\hline +Ve : diabetic group(positive) & \multicolumn{2}{|c|}{$7.80^{a}$} & \multicolumn{2}{|c|}{$85.500^{a}$} & \multicolumn{2}{|c|}{$82.50^{\mathrm{a}}$} \\
\hline Feeding period & 3 weeks & 6 weeks & 3 weeks & 6 weeks & 3 weeks & 6 weeks \\
\hline \multicolumn{7}{|l|}{ Group } \\
\hline G1 & $6.75^{\mathrm{a}}$ & $6.59^{\mathrm{b}}$ & $62.00^{\mathrm{a}}$ & $77.50^{\mathrm{ab}}$ & $82.50^{\text {a }}$ & $64.00^{\mathrm{b}}$ \\
\hline G2 & $7.21^{\mathrm{a}}$ & $6.66^{\mathrm{b}}$ & $80.00^{\mathrm{a}}$ & $80.00^{\mathrm{ab}}$ & $71.50^{\mathrm{ab}}$ & $74.00^{\mathrm{ab}}$ \\
\hline G3 & $6.43^{\mathrm{a}}$ & $6.51^{\mathrm{b}}$ & $72.50^{\mathrm{a}}$ & $62.00^{\mathrm{d}}$ & $63.00^{\mathrm{b}}$ & $82.50^{\mathrm{a}}$ \\
\hline G4 & $6.80^{\mathrm{a}}$ & $6.89^{\mathrm{b}}$ & $67.00^{\mathrm{a}}$ & $67.00^{\mathrm{cd}}$ & $59.50^{\mathrm{b}}$ & $64.00^{\mathrm{b}}$ \\
\hline G5 & $4.38^{\mathrm{a}}$ & $6.74^{\mathrm{b}}$ & $64.50^{\mathrm{a}}$ & $74.50^{\mathrm{bc}}$ & $67.00^{\mathrm{ab}}$ & $67.50^{\mathrm{ab}}$ \\
\hline LSD & 3.42 & 6.74 & 30.97 & 10.27 & 18.78 & 17.12 \\
\hline
\end{tabular}

Values with different letters in the same column or row are significantly different $(\mathrm{P}<0.05)$

-Ve (control): normal group +Ve (control): diabetic group

G1 : normal group (-Ve) G2 : diabetic group (+Ve)

G3: diabetic group and fed 5\% Rusk G4: diabetic group and fed 5\%PR (PR containing 10\% physalis)

G5: diabetic group and fed 5\%PR (PR containing 20\% physalis) 
Table 6. Impact of Physalis Rusk on the kidney functions

\begin{tabular}{|c|c|c|c|c|}
\hline Lipid profile & \multicolumn{2}{|c|}{$\begin{array}{c}\text { Creatinine } \\
\text { (mg-dl) }\end{array}$} & \multicolumn{2}{|c|}{$\begin{array}{c}\text { Urea } \\
\text { (mg-dl) }\end{array}$} \\
\hline -Ve: normal group(negative) & \multicolumn{2}{|c|}{$0.77^{\mathrm{a}}$} & \multicolumn{2}{|c|}{$33.215^{\mathrm{e}}$} \\
\hline +Ve: diabetic group(positive) & \multicolumn{2}{|c|}{$0.85^{\mathrm{a}}$} & \multicolumn{2}{|c|}{42.925 ab } \\
\hline Feeding period & 3 weeks & 6 weeks & 3 weeks & 6 weeks \\
\hline \multicolumn{5}{|l|}{ Group } \\
\hline G1 & $0.77^{\mathrm{a}}$ & $0.81^{\mathrm{a}}$ & $35.16^{\mathrm{d}}$ & $36.37^{\text {cd }}$ \\
\hline G2 & $1.01^{\mathrm{a}}$ & $1.085^{\mathrm{a}}$ & $43.75^{\mathrm{a}}$ & $44.71^{\mathrm{a}}$ \\
\hline G3 & $0.57^{\mathrm{a}}$ & $0.62^{\mathrm{a}}$ & $42.21^{\mathrm{ab}}$ & $41.00^{\mathrm{abc}}$ \\
\hline G4 & $0.80^{\mathrm{a}}$ & $0.90^{\mathrm{a}}$ & $41.16^{\mathrm{b}}$ & $39.39^{\mathrm{bc}}$ \\
\hline G5 & $0.77^{\mathrm{a}}$ & $0.80^{\mathrm{a}}$ & $38.66^{\mathrm{c}}$ & $39.22^{\mathrm{bc}}$ \\
\hline LSD & 0.56 & 0.79 & 1.91 & 4.94 \\
\hline
\end{tabular}

Values with different letters in the same column or row are significantly different $(\mathrm{P}<0.05)$

-Ve (control): normal group $\quad+\mathrm{Ve}$ (control): diabetic group

G1 : normal group(-Ve) G2 : diabetic group (+Ve)

G3: diabetic group and fed 5\% Rusk G4: diabetic group and fed 5\%PR(PR containing 10\% physalis)

G5: diabetic group and fed 5\% PR (PR containing 20\% physalis)

\section{Histopathological examination}

\section{Group G1: Normal control untreated group (Negative)}

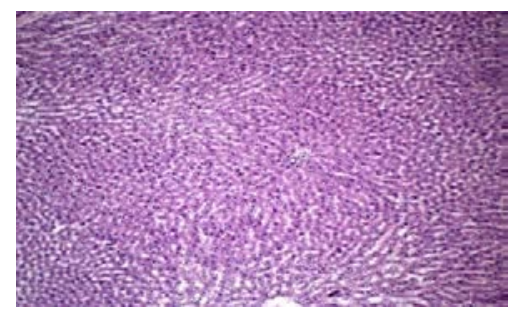

Fig. 1. Liver tissue control of rat $H$ and $E$

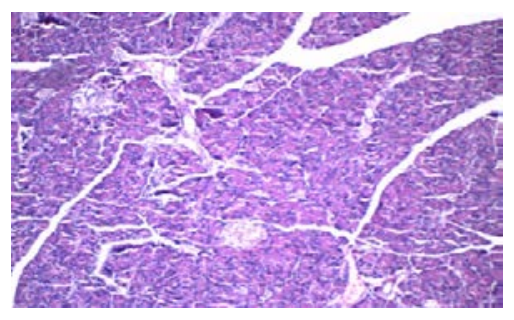

Fig. 2. Pancreas tissue of rat $\mathrm{H}$ and $\mathrm{E}$ (X300)

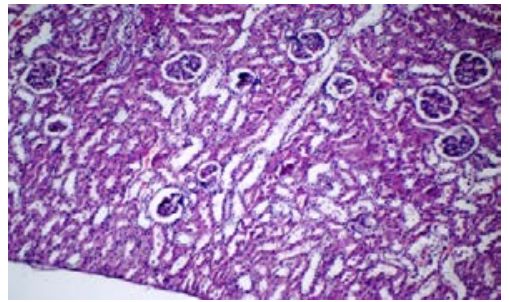

Fig. 3. Kidney tissue of rat showing $H$ and $E$ (X300)

Group G2: Diabetic group (Positive)

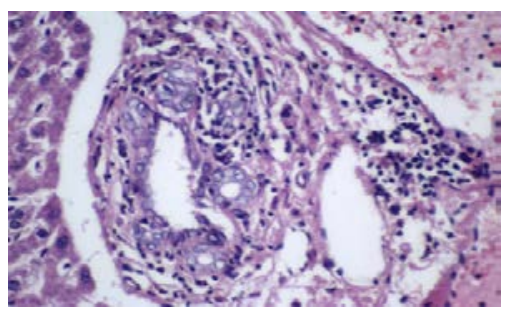

Fig. 4. Liver tissue diabetic rats (positive control of group G2) $H$ and $E$ (X300)

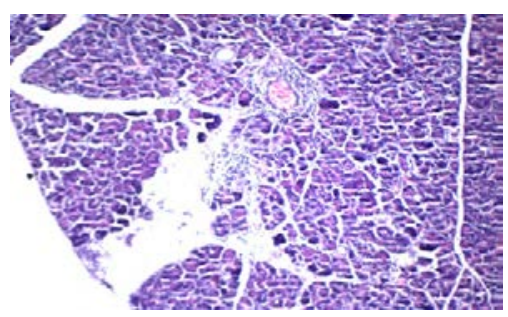

Fig. 5. Pancreas tissue of diabetics rat (positive control of group G2) $H$ and $E$ (X1200)

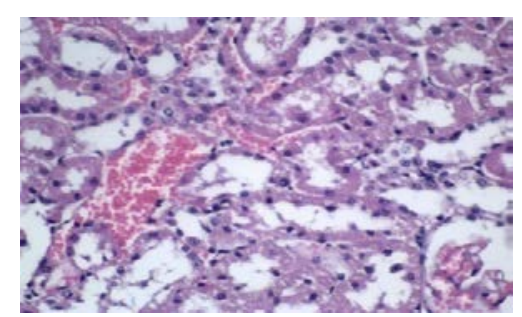

Fig. 6. Kidney tissue of diabetics rat (positive control of group G2) showing $H$ and $\mathrm{E}(\mathrm{X1200})$ 
Rats fed on 5\% Rusk showed the intense acute cell swellings or mild reversible changes still present in the hepatic cells beside portal lymphocytic infiltration and extend to the interstitial tissues and individual's apoptotic hepatocytes were observed in liver (Fig. 7). Pancreas was Hypocellularity, vacuolated cytoplasm Langerhans, pyknotic and karyorrhexis of nuclei (Fig. 8). Also renal duct necrosis and indothelyosis of blood vessels degeneration and mild vacillation in kidney (Fig. 9).

In liver tissue of diabetics rats and fed on 5\%PR was intense acute cell swellings or mild reversible changes still present in the hepatic cells beside portal lymphocytic infiltration reducing. While severe congestion in portal blood vessels and sinusoids could be seen (Fig. 10). Also pancreas endocrine cells of Islets showed intense degeneration and necrosis of endocrine pancreas (Fig. 11). Kidney tissue showed that the renal parenchyma appeared normal (Fig. 12).

Liver tissue indicated that some hepatic cells still exhibited microsteatosis or acute cell swelling and other had clusters from programmed cell death (apoptosis) (Fig. 13). Portal edema, congested hepatic vessels, lymphocytic infiltration and proliferation of bile duct epithelium were encounted. Hylanized vascular wall of hepatic arteriole and mild fibroblastic proliferation could be seen in liver portal areas and reducing compared with Fig. 10. The pancreatic tissues were normal in Fig. 14. Kidney tissue in Fig. 15 show that congested glomerular tufts, capillaries, blood vessels was common. Other glomeruli had lobulated and contracted tufts with cystic and dilation of Bowmans capsule. Focal tubular necrosis manifested by pyknotic nuclei, destructed tubular epithelium with presence of granular or hyaline casts.

The results in histopathological of Physalis Rusk supplemention seems to protect the liver in response to oxidative stress (probably via the elevation of antioxidant enzymes levels). Therefore, it could be suggested that the use of physalis Rusk with high antioxidant potential by patients suffering from diabetic would prevent development of these diseases. The results agree with Hassan and Ghoneim, (2013) who observed that the polyphenols content of the fresh physalis juice was found to be $70 \mathrm{mg} / 100 \mathrm{ml}$. Physalis polyphenols may, therefore, prevent the damage and death of pancreatic -cells and/or stimulate the regeneration of this type of cells in diabetic rats.

\section{Conclusion}

The results of the in vivo experiment indicate that the administration of physalis has a profound influence on the metabolism of lipids and glucose in alloxanized diabetic rat. Physalis positively affects the blood profile of alloxanized diabetic rat. The TC, LDL, blood glucose and TG concentrations in the physalis Rusk groups were significantly lower than those in the positive control group. The positive influence on blood lipids was good in the groups of rats fed on physalis Rusk, which possesses high antioxidant potential. The results suggest that consumption of physalis Rusk has significant hypoglycemic activities in alloxanized diabetic rat. Results indicated severe hepatic steatosis in rats.

From the foregoing results in the current work, it could be recommended to add physalis paste at a ratio of 10 or $20 \%$ during the manufacture of Rusk to get the healthy and nutritional benefits of this product.

\section{Group G3 : Diabetic group and fed 5\% Rusk}

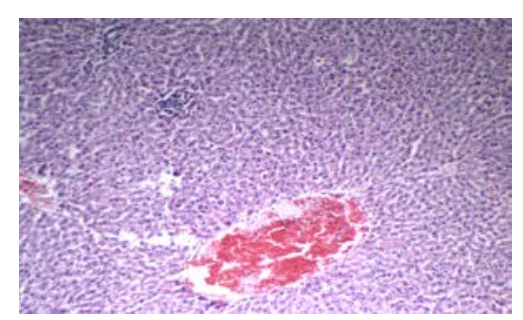

Fig. 7. Liver tissue of diabetics rat and fed $5 \%$ Rusk G3 $\mathrm{H}$ and $\mathrm{E}$ (X300)

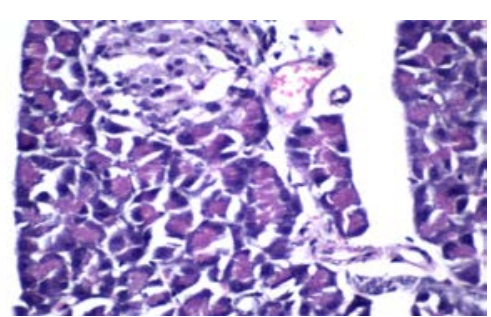

Fig. 8. Pancreas tissue of diabetics rat and fed $5 \%$ Rusk G3 $H$ and $E$ (X1200)

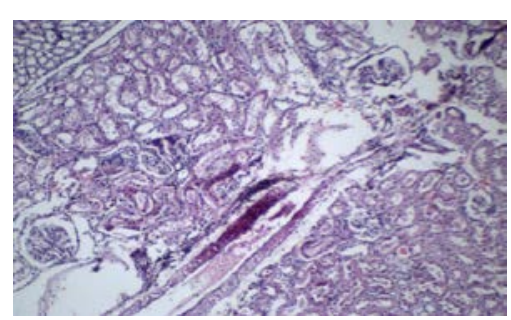

Fig. 9. Kidney tissue of diabetics rat and fed $5 \%$ Rusk G3 $\mathrm{H}$ and $\mathrm{E}$ (X300) 
Group G4: Diabetic group and fed 5\%PR (PR containing 10\% physalis)

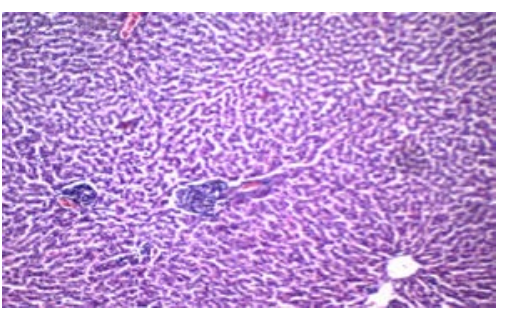

Fig. 10. Liver tissue of diabetics rat and fed $5 \%$ PR (PR containing 10\% physalis) $\mathrm{G} 4 \mathrm{H}$ and $\mathrm{E}$ (X300)

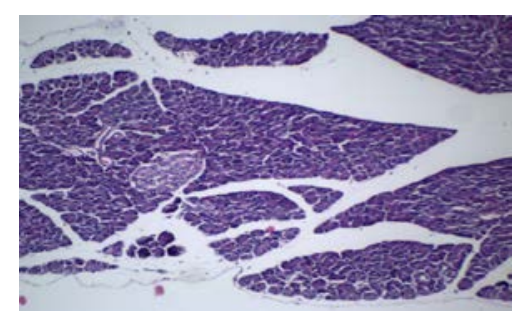

Fig. 11. Pancreas tissue of diabetics rat and fed 5\% PR (PR containing $10 \%$ physalis) G4 $\mathrm{H}$ and $\mathrm{E}$ (X300)

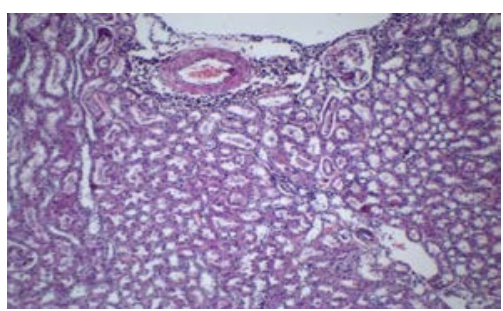

Fig. 12. Kidney tissue of diabetics rat and fed 5\% PR (PR containing $10 \%$ physalis) $\mathrm{G} 4 \mathrm{H}$ and $\mathrm{E}(\mathrm{X} 300)$

Group G5: Diabetic group fed on 5\% PR (PR containing 20\% physalis)

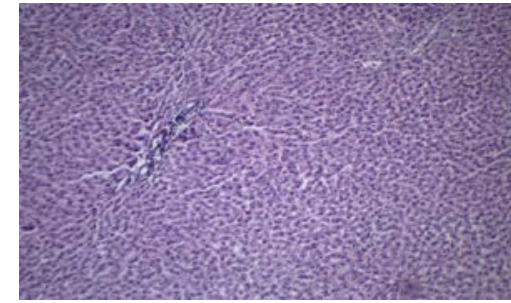

Fig. 13. Liver tissue of diabetics rat fed on $5 \%$ PR (PR containing $20 \%$ physalis) $\mathrm{G} 5 \mathrm{H}$ and $\mathrm{E}$ (X300)

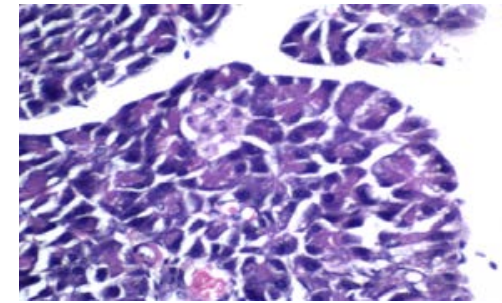

Fig.14. Pancreas tissue of diabetics rat fed on $5 \%$ PR (PR containing $20 \%$ physalis) $\mathrm{G} 5 \mathrm{H}$ and $\mathrm{E}$ (X1200)

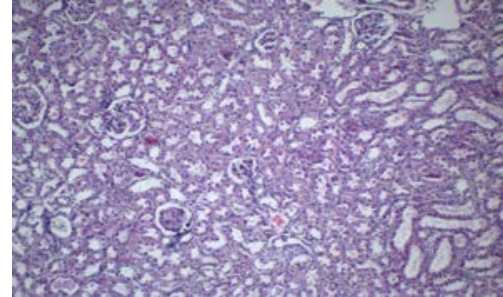

Fig. 15. Kidney tissue of diabetics rat and fed 5\% PR (PR containing $20 \%$ physalis) $\mathrm{G} 5 \mathrm{H}$ and $E$ (X1200)

\section{REFERENCES}

AOAC (2010). Official Methods of Analysis of Assocation of Official Agriculture Chemists, Washington D.C.

Aslan, M., D.O. Deliorman, N. Orhan, E. Sezik, and E. Yesilada (2007a). In vivo antidiabetic and antioxidant potential of Helichry sumplicatum ssp. Plicatum capitulums in streptozotocin-induced diabetic rats. J. Ethnophar, 109: 54-59.

Aslan, M., D. Deliorman, N. Orhan, E. Sezik and E. Yesilada (2007b). A study of antidiabetic and antioxidant effects of
Helichrysum graveolens capitulums in streptozotocin-induced diabetic rats. J. Med. Foods, 10: 396-400.

Balasubramaian, R., R. Kasiappan, N., Vengidusamy, K. Muthusamy and S., Sorimuthu (2004). Protective effect of macrocyclic binuclear oxovanadium complex on oxidative stress in pancreas of streptozotocin induced diabetic rats. Chemico- Biol. Inter., 149, 9-21.

Choi, H.S., K.M. Do, Y.B. Park, S.M. Jeon, T. Jeong, Y.K. Lee, M.K. Lee and S.H. Bok (2001). Effect of naringenin supplementation 
on cholesterol metabolism and antioxidant status on rats fed high cholesterol with different levels of vitamin E. Ann. Nut. Metab., 45: 193-201.

Daher, C.F., F.G. Baroody and M.G. Baroody (2006). Effect of Urtica dioica extract intake upon blood lipid profile in the rats. Fitoterapia, 77 : 183-188.

Despres, J.P. (2006). Is visceral obesity the cause of the metabolic syndrome? Annal. Med., 38: 52-63.

Diana P. R., F. Luis and D. Marcela (2015). Inhibitory effects of an extract of fruits of Physalis peruvianaon some intestinal Carbohydrases. Rev. Colomb. Cienc. Qudm. Farm., 44 (1): 72-89,

Feoli, A.M., C. Roehrig, L.N. Rotta, A.H. Kruger, K.B. Souza, A.M. Kesseler, S.V. Renz, A.M. Brusque, D.O. Souza and M.L.S. Perry (2003). Serum and liver lipids in rats and chicks fed with diets containing different oils. Nut., 19: 789-793.

Filipovic, V., J. Filipovic, J. Gvozdenovic and D. Novakovic (2012). Packaging material characteristics contributing to shelf-life of rusk. Romanian Biotechnol. Lett., 17 (2): 7125-7135.

Fliiopovic, N. and M.J. Gyura (2007). The effect of type and quantity of sugar-beet fibers on bread characteristics, J. Food Eng., 78 : 1047-1053.

Fliiopovic, N., G. Kaludjerski, K. Vranac, Z. Vrbski and N. Sstancovic (1991). Influence of pan release grease on the Rusk shelf-life, Cereal-Bread, 18: 13-17

Gordon, T.M. (1977). HDL-Cholesterol determination after separation higher density lipoprotein lipid. Ame. J. Med., 62: 707.

Gutteridge, J.M. (1995). Lipid peroxidation and antioxidants as biomarkers of tissue damage. Clinic Chem., 41:1819-1828.

Häkkinen, S.H., S.O. Kärenlampi, I.M. Heinonen, H.M. Mykkänen and A.T. RIitta (1999). Content of the flavono lsquercetin, myricetin, and kaempferolin 25 edible berries. J. Agric. Food Chem., 47: 22742279.
Hassan, A.I. and M.A.M. Ghoneim (2013). A possible inhibitory effect of physalis (Physalis pubescens L.) on diabetes in male rats. World Appl. Sci. J., 21 (5): 681-688.

Jelodar, G., Z. Khaksar and M. Pourahmadi, (2010).Endocrine profile and testicular histomo PRhometry in neonatal rats of diabetic mothers. Vet Arhiv, 80 (3): 421-430.

Meilgard, M., G.V. Civille and B.T. Carr (1991). Sensory Evaluation Techniques. $2^{\text {nd }}$ Ed. Florida, USA: CRC Press, 354.

Murugesan, S. and S.P. Subramanian (2015). Physalis peruviana L. fruits avert oxidative stress in pancreatic and hepatic tissues of streptozotocin induced diabetic rats. Scholar Res. Lib., 7 (4) : 59-73.

Olaoye, O.A. and A.A. Onilude (2008). Microbiological, proximate analysis and sensory evaluation of baked products from blends of wheat breadfruit flours. Afr. J. Food Agric. Nut. Dev., 8 (2): 192-203.

Pandey, K.B. and S.I. Rizvi (2010). Antioxidative action of resveratrol: implications for human health. 46. Bansal, R., 2008. Alloxan and streptozotoanaction” Arab J. Chem., 6: 1-6

Parminder, N., S. Vipin, S. Sunil and N. Jaspreet (2012). Anti diabetic and anti oxidant potential of Emblica officinalis Gaertn. leaves extract in streptozotocininducedtype-2 diabete smellitus (T2DM) rats. J. Ethnopharmacol., 142 : 65-71.

Poster L. (1991). Laboratory Methods for Sensory Analysis of Food. Ottawa Agric., Canada, Phistol., 210.

Ramadan, M.F., N.A. Hassan, R.M. Elsanhoty and M.Z. Sitohy (2013). Goldenberry (Physalis peruviana) juice rich in health-beneficial compounds suppresses highcholesterol dietinduced hypercholesterolemia in rats. J. Food Bio., 37 (6): 708-722.

Ramadan, M.F. (2011). Bioactive phytochemicals, nutritional value, and functional properties of cape gooseberry (Physalis peruviana): An overview. Food Res. Int., 44: 1830-1836. 
Ramadan, M.F. and J.T. Moersel (2004). Goldenberry: a noval fruit source of fat soluble bioactives. Information, 15: 130-131.

Ramadan, M.F. and J.-T. Mörsel (2007). Impact of enzymatic treatment on chemical composition, physicochemical properties and radical scavenging activity of goldenberry (Physalis peruviana L.) Juice J. Sci. Food Agric., 87: 452-460.

Shaw, J.E., R.A. Sicree and P.Z. Zimme (2010). Global estimates of the prevalence of diabetes for 2010 and 2013. Diabetes Res. and Clin. Practice, 87: 4-14.
Steel, R.G.D. and J.H., Torrie, (1980).Principles and Procedures of Statistics. McGraw, New York.

Stein, E.A. (1987). Lipids, lipoproteins, and apo-lipoproteins. In : Tietz NW, Ed. Fundamentals of Clinical Chemistry. $3^{\text {rd }}$ Ed. Philadelphia: WB Saunders, 448-481.

Suvarna S.K., C. Layton and J.D. Bancroft (2013). Bancroft's Theory and Practico of Histological Technigues. $7^{\text {th }}$ Ed., Churchill Livingstone. Elsevier, England.

Young, D.S. (2001). Effects of disease on Clinical Lab. Tests, $4^{\text {th }}$ Ed. AACC.

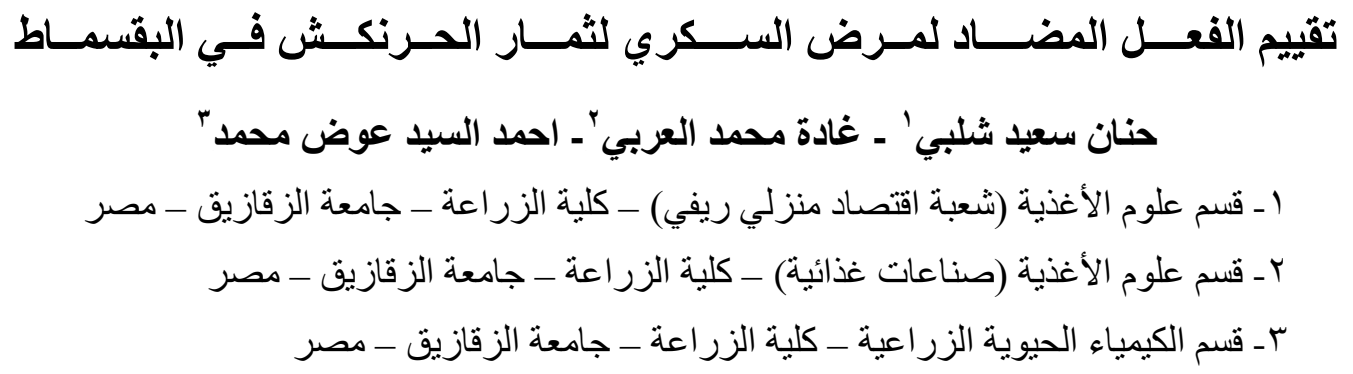

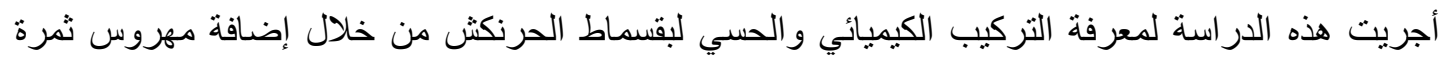

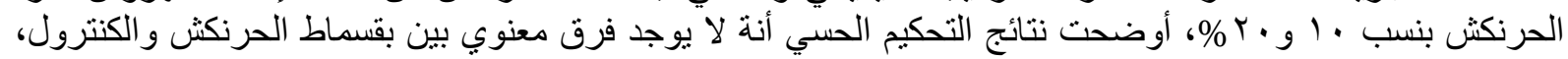

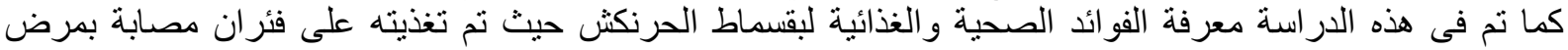

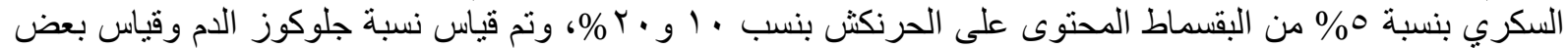

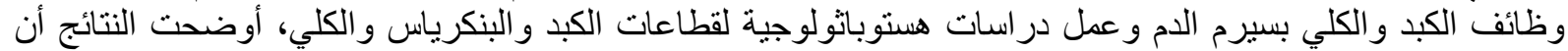

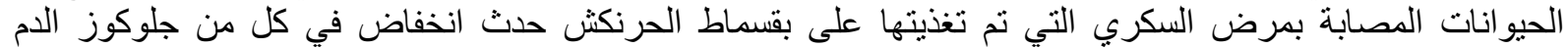

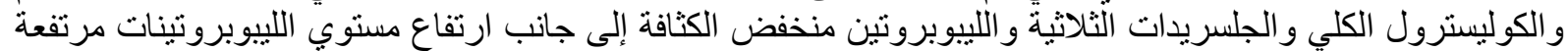

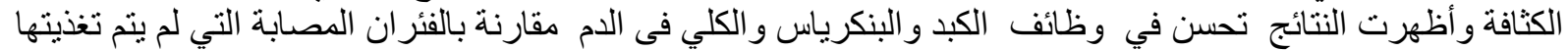

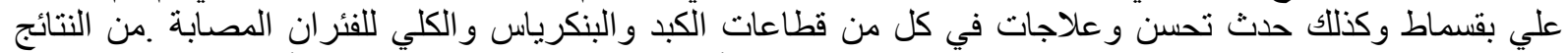

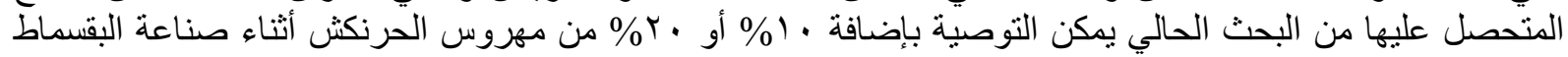

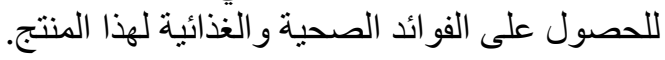

